\title{
Causal Analysis of Ecological Impairment in Land Ecosystem on a Regional Scale: Applied to a Mining City Daye, China
}

\author{
Kai Guo ${ }^{1}$, Yiyun Chen ${ }^{2, *} \mathbb{C}$, Min Chen ${ }^{3}$, Chaojun Wang ${ }^{4}$, Zeyi Chen ${ }^{2}$, Weinan Cai ${ }^{1}$, Renjie Li ${ }^{1}$, Weiming Feng ${ }^{1}$ \\ and Ming Jiang ${ }^{1}$ \\ 1 School of Geography and Remote Sensing, Guangzhou University, Guangzhou 510006, China; \\ guokai@gzhu.edu.cn (K.G.); caiwn@e.gzhu.edu.cn (W.C.); 2111901051@e.gzhu.edu.cn (R.L.); \\ 2112001051@e.gzhu.edu.cn (W.F.); 2112001065@e.gzhu.edu.cn (M.J.) \\ 2 School of Resource and Environmental Sciences, Wuhan University, Wuhan 430079, China; \\ chen_zy@whu.edu.cn \\ 3 Guangzhou Urban Planning \& Design Survey Research Institute, Guangzhou 510060, China; \\ 2018282050161@whu.edu.cn \\ 4 Jiangsu Vocational College of Medicine, Yancheng 224005, China; 11834@jsmc.edu.cn \\ * Correspondence: chenyy@whu.edu.cn; Tel.: +86-177-8648-6713
}

\section{check for} updates

Citation: Guo, K.; Chen, Y.; Chen, M.; Wang, C.; Chen, Z.; Cai, W.; Li, R.; Feng, W.; Jiang, M. Causal Analysis of Ecological Impairment in Land Ecosystem on a Regional Scale: Applied to a Mining City Daye, China. Land 2021, 10, 530. https:/ / doi.org/10.3390/land10050530

Academic Editors:

Oimahmad Rahmonov,

Jacek Róźkowski and Grzegorz Kłys

Received: 21 March 2021

Accepted: 10 May 2021

Published: 17 May 2021

Publisher's Note: MDPI stays neutral with regard to jurisdictional claims in published maps and institutional affiliations.

Copyright: (c) 2021 by the authors. Licensee MDPI, Basel, Switzerland. This article is an open access article distributed under the terms and conditions of the Creative Commons Attribution (CC BY) license (https:/ / creativecommons.org/licenses/by/ $4.0 /)$.

\begin{abstract}
We adopted a weight of evidence approach to establish a causal analysis of an impaired land ecosystem on a regional scale; namely, Daye, a traditional mining city in China. Working processes, including problem statements, a list of candidate causes, and a conceptual model were developed to represent a causal hypothesis for describing land degradation. Causal criteria were applied to integrate multiple lines of evidence. Then, various pieces of evidence were scored to either strengthen or weaken our causal assumptions. Results showed that habitat alteration, heavy metal accumulation, organic pollutants, water eutrophication, and nutrient runoff were the probable causes of land ecosystem impairment in Daye. Meanwhile, noxious gas, toxicants, altered underground runoff, atmospheric deposition, and acid rain were identified as possible causes. The most unlikely causes were altered hydrology, altered earth surface runoff, and soil erosion. Soil salinization, soluble inorganic salts, biological species invasion, and pathogens were deferred as delayed causes due to lack of adequate information. The causal analysis approach was applied to identify the primary causes of land degradation and implement accurate protective measures in an impaired land ecosystem.
\end{abstract}

Keywords: regional causal analysis; weight of evidence; multiple causes; land ecosystem

\section{Introduction}

Land ecosystems are highly important life-support systems worldwide, and they play an essential role in ecological performance and socioeconomic development [1,2]. However, the unsustainable mining activities of human beings, including industrial land sprawl, the overpumping of underground water, the discharge of industrial wastewater and exhaust, mineral processing and smelting, large areas of solid waste piles and transportation, and deforestation, have led to extensive ecological degradation [3,4]. Examples of ecological degradation include soil erosion, desertification, soil pollution, the loss of natural habitats, and the sharp decline of arable land, which lead to land productivity decline, biodiversity reduction, human health and food safety problems, population overload, and ecological refugees [5-7].

For the mining city, land degradation has a long incubation period and ultimately leads to the serious unsustainable development of human beings [1,8]. Thus, a method that can accurately identify the causes of such a phenomenon should be developed. A causal analysis of an impaired land ecosystem is essential to determine state and degradation trends and ecological mechanisms, identify the causes of such a phenomenon, establish a mutual relation among land usage and high-quality risk assessment, and adopt efficient solutions for land ecological crises. 
Establishing causal relationships between environmental stressors and observed effects on regional land ecosystems is difficult. This problem is due to various human disturbances and the intrinsic complexity of land ecosystems. Moreover, no widely accepted approach for determining such relationships is available. Most diagnoses of land ecological problems focus on various single issues, such as barren fields, drought, desertification, saline-alkali land, contaminated sites, wetland function degradation, and landscape diversity loss [9-11]. These mono-factor analyses are significant but are unable to represent the mechanisms of land ecosystem degradation on a region scale. In addition, scale control is an important factor in the causal analysis of regional land ecosystems. Land degradation is only reflected on a large scale, which represents the entire ecological function and health. For example, some ecological factors may be tolerable when they occur individually. However, when several factors simultaneously occur in a particular region, they will produce integrative ecological effects, such as the transfer of heavy metal contamination, the expansion of contaminated water, and extensive river blanking, which may overwhelm local land ecosystems [12-14]. Our understanding of ecological linkages and fate and transport pathways broaden as these problems expand $[15,16]$.

The following methods and technologies have been used to conduct causal analysis research in land ecosystems on a larger scale. Laboratory experiments and field studies were combined to diagnose potential hazards $[17,18]$. Statistical analyses combined with a geographic information system (GIS) was used frequently for highlighting the distribution of the environmental degradation and risk sources, and endpoints [19]. A conceptual model was developed to present the complex relationships of ecological degradation [20,21]. Characteristic causal analysis was designed following the scientific assumptions of the discipline itself $[22,23]$. Multi-metric indexes were designed based on local key traces to identify the environmental stressors such as chemical, physical, biological, and socialeconomic [24-26] via the structural analysis of the whole system to simulate the causal mechanisms $[27,28]$. Lastly, various risk-based methodologies displayed the process of the function loss in the terrestrial ecosystem [29].

Current diagnosis methods overemphasize quantitative approaches, such as field sampling, experimental data analysis, statistical analysis, and model building [30]. However, such methods are costly depending on the required data and their quality, thereby limiting evidence selection. Consequently, ecologists experience difficulty in establishing risk hypotheses. In addition, causal analysis is accompanied with the development of ecological risk assessment. Numerous studies in this field have mostly focused on the causes of toxic and harmful substances. However, regional ecological risk assessments for large-scale areas are currently increasing, thereby indicating that entire ecosystem problems should be given considerable attention. Therefore, causal analysis methods must also keep up with changes in large-scale ecosystems. Moreover, qualitative approaches, including social survey, experience cognition, and expert assessment, are essential considering that land ecosystems are complex syntheses of nature and the social economy.

The weight of evidence (WOE) approach interprets lines of evidence for identifying complicated interactions, thereby providing assistance to assessors in verifying multiple hypotheses in complex ecosystems [31-33]. Numerous studies have detailed the principle of this method, whereas different causal analysis studies have focused on its developments [34-36].

The WOE method is extremely useful in guiding causal analysis procedures, particularly the manner by which various pieces of evidence are combined to identify stressors, such as chemical, physical, and biological ones, which cause the impairment of a complex ecosystem $[35,37]$. This approach embodies the combination of qualitative and quantitative methods and compensates for the disadvantages of single methods $[33,38]$. The WOE approach not only introduces quantitative methods for experiments, modeling, and statistical analyses, but also includes social investigations, such as interviews, questionnaires, and feedback channel construction. Simultaneously, the application of this framework is easy to enhance and update in different causal analysis research $[39,40]$. In addition, such 
application is highly important for follow-up work, including environmental investigations, database formation, risk communication, ecological modeling, simulation calculation, uncertainty problems, whether to promote preferred management actions, and support for legal opinions on ecological protection [16,41,42].

In this study, the WOE method was used in the causal assessment of an impaired land ecosystem in a mining area, i.e., Daye, a traditional mining city in China. Multiple lines of evidence were evaluated on the basis of the causal criteria for identifying probable causes. Our work highlights complicated ecological mechanisms, such as physical, chemical, and biological mechanisms, that cause ecological and human health damages, on a large-scale area. It can even help establish follow-up research, including effective ecological risk assessments, the identification of risk sources, decision making in eco-protection, and ecological restoration.

\section{Materials and Methods}

\subsection{Study Region}

\subsubsection{Description of the Study Area}

Daye City is located in the southeast of Hubei Province in Central China (114 $31^{\prime}$ $115^{\circ} 20^{\prime} \mathrm{E}, 29^{\circ} 40^{\prime}-30^{\circ} 15^{\prime} \mathrm{N}$ ) near the Yangtze River (Figure 1). The area is rich in mineral deposits, with well-developed mining and metallurgy industries. The ecosystem in and around the city is wide-ranging, with lakes, rivers, forests, mines, arable lands, gardens, and urban and rural residential areas. The entire study area is $1566.3 \mathrm{~km}^{2}$.

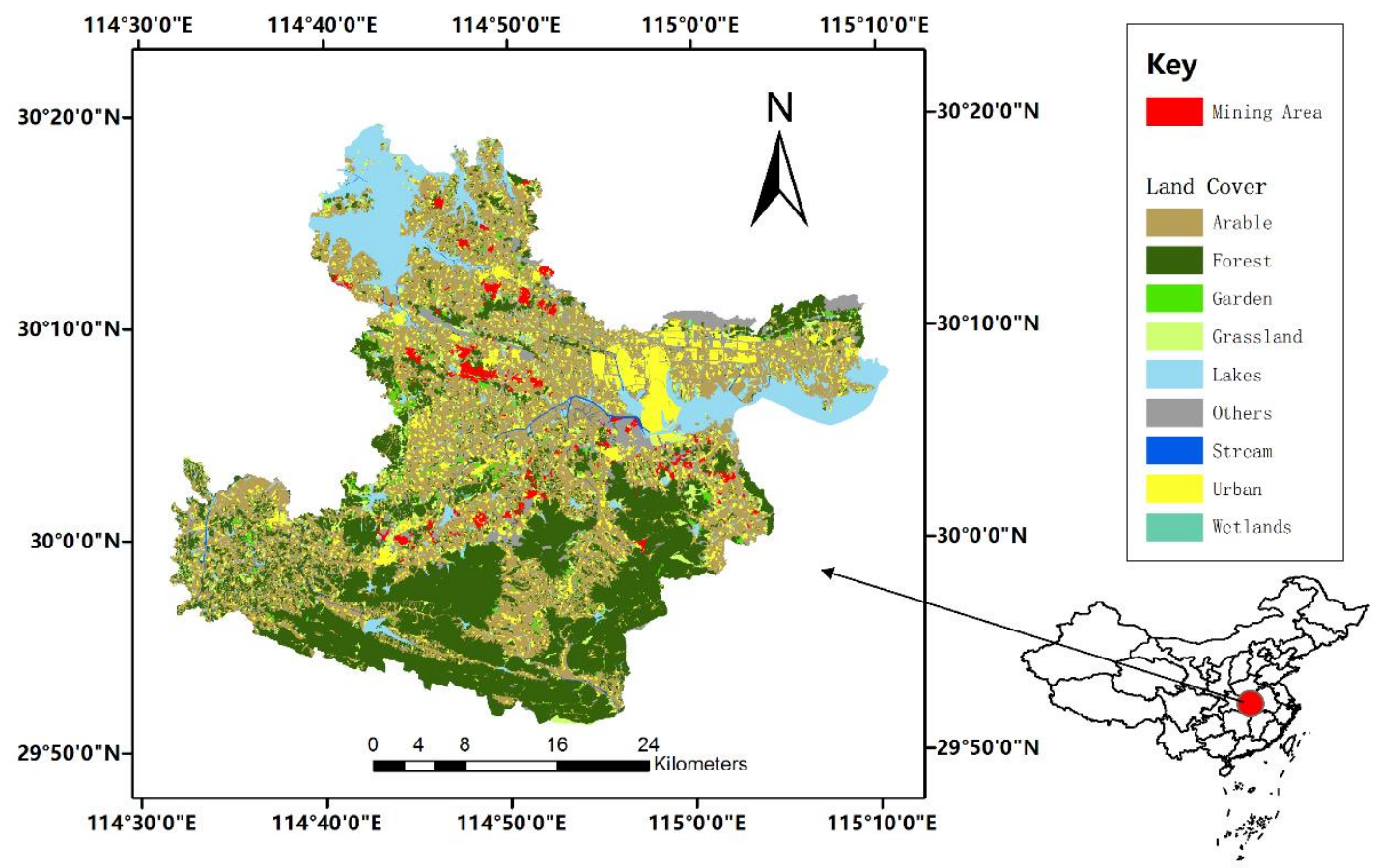

Figure 1. Map showing location of Daye City and its mining distribution.

\subsubsection{Data Source}

A total of 225 valid soil samples were identified throughout the study area in 2016. Soil degradation was investigated on the basis of the following indicators: soil quality (organic matter content), soil acidification ( $\mathrm{pH}$ value), soil erosion (surface soil and water loss amounts), and soil texture (soil layer thickness, gravel content, and soil coarsening).

Our research group selected $\mathrm{Cu}, \mathrm{Pb}, \mathrm{Cd}$, and As to determine their contents in the 225 soil samples. Atomic absorption spectrophotometry was performed in the laboratory to determine the contents of $\mathrm{Cu}, \mathrm{Pb}$, and $\mathrm{Cd}$. Meanwhile, the barium chromate spectrophotometric method was used to identify content of As. The Nemerow index was applied to 
calculate the single values of the heavy metals, i.e., $\mathrm{Cu}, \mathrm{Pb}, \mathrm{Cd}$, and $\mathrm{As}$, and the Nemerow composite index (Table 1). The aforementioned soil component measurements and heavy metal content data based on the geographical coordinates (Global Positioning System data) of the soil samples and the remote sensing image and elevation data of the study area were processed into spatial data and integrated into a geographic information system (GIS).

Table 1. The tested samples of heavy metals content, Nemero single value, and Nemerow composite index in Daye area.

\begin{tabular}{|c|c|c|c|c|c|c|c|c|c|}
\hline \multirow{2}{*}{ Id } & \multicolumn{4}{|c|}{ Heavy Metal Content } & \multicolumn{4}{|c|}{ Nemero Single Value } & \multirow{2}{*}{ Nemerow Composite Index } \\
\hline & $\mathrm{Cu}$ & As & $\mathrm{Cd}$ & $\mathbf{P b}$ & $\mathrm{Cu}$ & As & $\mathrm{Cd}$ & $\mathbf{P d}$ & \\
\hline 2 & 20.99 & 16.87 & 1.05 & 19.25 & 0.68 & 1.37 & 6.18 & 0.72 & 4.65 \\
\hline 8 & 26.95 & 12.23 & 1.05 & 62.55 & 0.88 & 0.99 & 6.18 & 2.34 & 4.74 \\
\hline 6 & 59.72 & 33.09 & 1.32 & 75.59 & 1.95 & 2.69 & 7.76 & 2.83 & 6.12 \\
\hline 3 & 13.26 & 22.19 & 1.12 & 58.84 & 0.43 & 1.80 & 6.59 & 2.20 & 5.05 \\
\hline 5 & 34.79 & 18.40 & 1.09 & 78.33 & 1.13 & 1.50 & 6.41 & 2.93 & 5.00 \\
\hline 4 & 24.88 & 23.00 & 1.10 & 83.65 & 0.81 & 1.87 & 6.47 & 3.13 & 5.06 \\
\hline 7 & 22.03 & 15.79 & 1.21 & 74.27 & 0.72 & 1.28 & 7.12 & 2.78 & 5.45 \\
\hline 1 & 20.38 & 4.03 & 1.17 & 69.65 & 0.66 & 0.33 & 6.88 & 2.61 & 5.21 \\
\hline 72 & 21.06 & 14.35 & 1.48 & 15.44 & 0.69 & 1.17 & 8.71 & 0.58 & 6.46 \\
\hline 76 & 22.28 & 11.46 & 1.18 & 78.85 & 0.73 & 0.93 & 6.94 & 2.95 & 5.32 \\
\hline$\ldots$ & & & & & $\ldots$ & & & & $\ldots$ \\
\hline
\end{tabular}

Our research group obtained the quarterly monitoring data of water quality in water bodies located in 37 monitoring points, including major rivers, lakes, and sensitive waters, from 2013 to 2018 on the basis of interviews and a survey conducted by the Daye Environmental Protection Bureau. The group selected chemical oxygen demand, NH3-N, and water eutrophication as criteria for water quality deterioration. A similar GIS spatial processing was performed on the basis of the geographical information of the sampling points.

The research team, together with the Daye City Land Resources Bureau, frequently organized investigations on the ecological environmental damage caused by mining in Daye (a traditional mining city) from 2013 to 2018. Investigation sites included $\mathrm{Cu}, \mathrm{Fe}$, coal, $\mathrm{Au}$, and $\mathrm{Ag}$ mines and related smelting sites, such as ore dressing sites, quarries, tailing reservoirs, coal gangue dumps, and open metal mines. Problems included over 800 damages to the Earth's surface and vegetation, 349 geological hazards (e.g., collapse, mine goaf, excavation, landslide, and water depletion), 550 land damages caused by solid waste dumping, and 1294 land plaques covering an area of 6943.58 ha. The research group conducted field investigations, plotting, and scene photography to obtain the information of each plot in terms of actual harm.

The data application of land use category was based on the land use maps of Daye in 2012. A substantial amount of data were obtained from the Daye Statistical Yearbook and social surveys, such as data on acid rain, particularly acid rain intensity released by the Daye Environmental Protection Bureau, and natural disasters collected from the historical information of Daye (1949-2016).

\subsection{Causal Analysis Framework}

Our work started with a plan of transformation, particularly the long-term ecological restoration, of resource-exhausted cities in the current Chinese government [43-46]. An operational framework was developed to serve as a guideline for identifying the primary causes for an impaired land ecosystem on a regional scale (Figure 2). We adopted the WOE approach to establish causation: (1) existing serious problems of impaired land ecosystems were introduced through group seminars; (2) our database based on field investigations and literature accumulation was proposed; (3) our list of candidate causes was obtained from various hypotheses; (4) a conceptual model was developed to exhibit the causal relationships of multiple stressors that caused impairment; (5) a WOE approach was applied to the analysis of various lines of evidence, and such pieces of evidence were scored 
to determine whether such causation was supported or weakened; and (6) discussions and uncertainty analysis were conducted $[47,48]$.

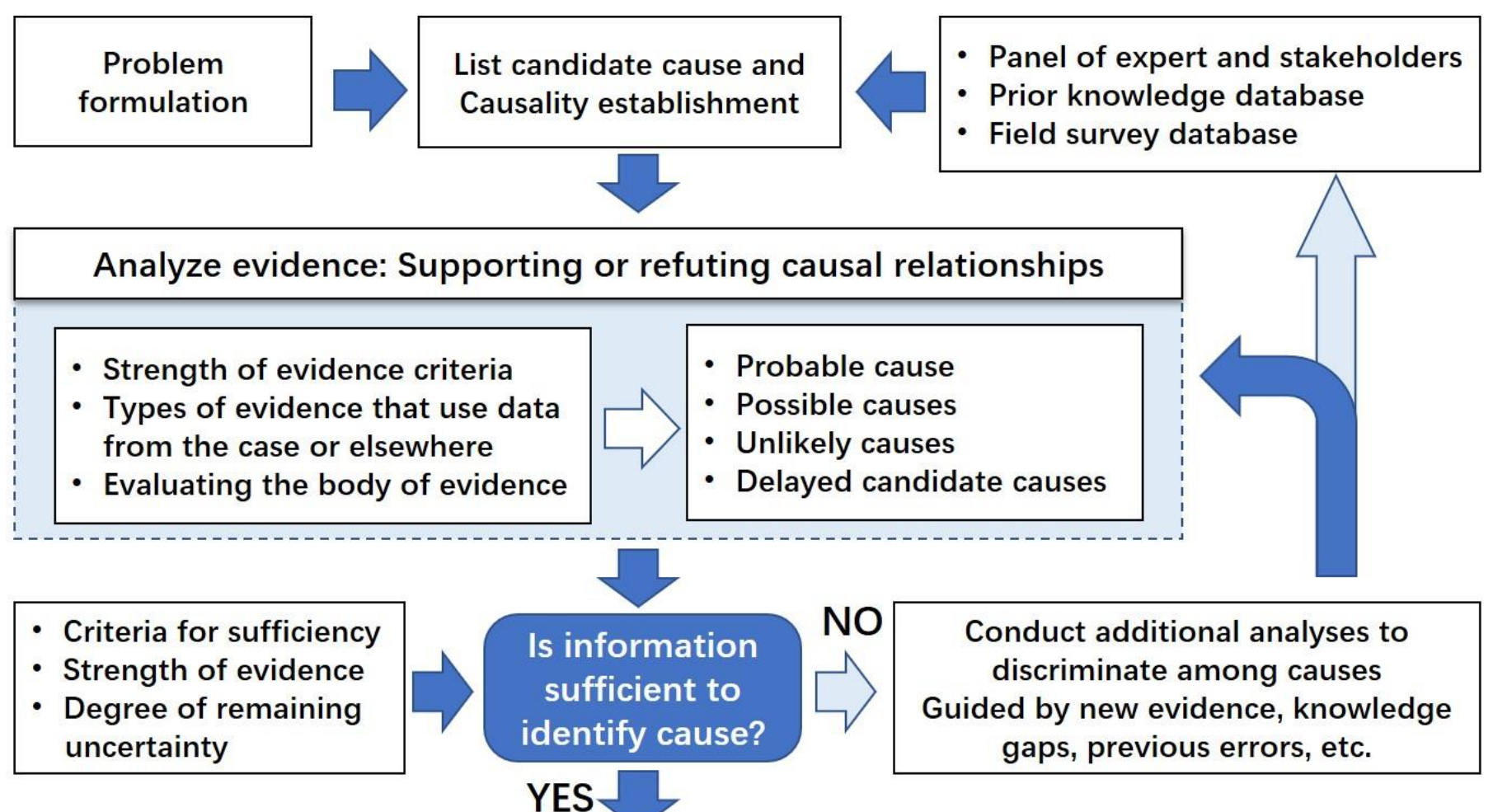

\section{Report results of causal analysis Summary and description at the seminar}

Figure 2. The procedure for regional causal analysis of land degradation in Daye area.

\subsection{Causal Analysis Design}

\subsubsection{Problem Formulation}

Problem formulation is a critical step in determining the evaluation range and target of ecological risk assessments $[49,50]$. Without this step, a problem will be exceedingly broad and will invite debates about its occurrence. Our study was motivated by the observation of serious problems about land degradation on a regional scale. Problem formulation was supported by field investigations, subsequent laboratory examinations, sufficient literature review, historical data provided by related local government departments, and current popular topics in environment fields. Seminars were conducted to refine the identified problems and focus on major ones. The following 11 problems were determined in the present study: (1) soil quality deterioration, (2) soil contamination, (3) water quality deterioration, (4) water shortage, (5) usable land shortage, (6) air pollution, (7) biodiversity decrease, (8) public safety and health threats (e.g., living condition deterioration), (9) land productivity decline, (10) eco-resiliency reduction (landscape heterogeneity loss), and (11) landscape aesthetic dysfunction. The identified problems reflect the current condition of land degradation in Daye City.

\subsubsection{List Candidate Cause}

After the problem statement was formulated, the next step was to establish a list of candidate causes that influence the stability and health of land ecosystems. A series of possible hypotheses should be effectively proposed to explain the manner by which these candidate causes lead to various observed negative ecological effects while diverging 
from the earlier hypothesis [51,52]. Candidate causes were determined in accordance with the aforementioned problems by a panel of experts (i.e., professors and local officials) from different but related fields (e.g., ecology, agronomy, geology, land resources, and urban development). These causes physically, chemically, and biologically affect land ecosystems in our study area. The following 30 causes were identified: (1) altered hydrology, (2) destroyed earth surface, (3) habitat removal, (4) altered earth-surface runoff, (5) altered underground runoff, (6) desertification, (7) soil erosion, (8) space occupation, (9) division of landscape, (10) edge effect, (11) atmospheric deposition, (12) soil salinization, (13) soil acidification, (14) solubility inorganic salt, (15) nutrient runoff, (16) organic pollutants, (17) heavy metals accumulation, (18) toxicants, (19) leaching, (20) water eutrophication, (21) sulfur deposition, (22) noxious gas, (23) acid rain, (24) changes in sedimentation patterns, (25) pathogens, (26) biological species invasion, (27) changes of the food chain, (28) geological disasters, (29) population overload, and (30) farmland abandoned.

\subsubsection{Causality Establishment}

After the initial list of candidate causes was completed by the study group, a hypothesis conceptual model that included the candidate causes was developed to represent the complete profile of land degradation in the study area. Meanwhile, various sources in Daye City were identified through familiarity with the local economic development patterns, particularly those concerning major pollutant-emitting enterprises $[7,31,53]$. Candidate causes from different sources that result in various hazardous effects depict complex interactions that can help understand potential mechanisms and promote the refinement of our list of candidate causes $[31,54]$ (Figure 3).

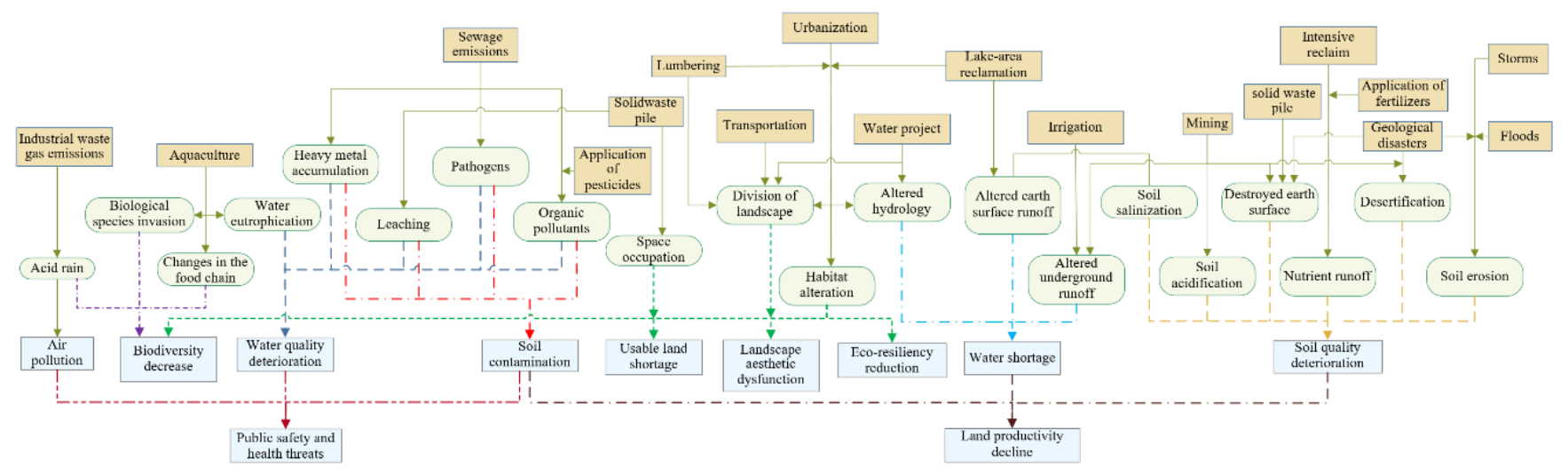

Figure 3. Conceptual model of land degradation in Daye area. The nodes were assigned to three groups: risk sources (orange), causes (green), and hazardous effects (blue) [1,42].

\subsection{Weighting and Scoring of Criteria}

\subsubsection{Causal Criteria}

The WOE approach combined different types of evidence to determine whether an apparent association of causes and effects is actually true $[36,38,55]$ This approach has been used in various applications related to environmental impacts on human health $[56,57]$. Then, USEPA developed this approach and frequently applied it to the causal assessments of various impaired ecosystems $[16,58]$. The identification result of the pathways of effects is also critical in determining the possible causes of any observed changes. Our study adopted Suter and Cormier's criteria [38,59], terrestrial systems by [16], and the USEPA causal analysis decision information system [54] for weighting evidence. We applied these mature standards to land ecosystems on a regional scale to make complicated ecological processes more practical and easier to understand. Meanwhile, various types of evidence were used to assess environmental causes of serious land degradation.

This principle of causal criteria was primarily obtained from Suter [33,38], Cormier [59], and the USEPA method [54] for identifying the performance of various pieces of evidence. 
The following are brief descriptions include 7 "types of evidence that use data from the case", and 3 "types of evidence that use data from elsewhere".

Types of evidence that use data from the case:

Spatial/temporal co-occurrence-ecological effects must be observed at the same time that causes occur. For example, in an aquaculture area, the boom season of breeding is also the time algae outbreaks occur. Similarly, industrial emissions upstream will lead to water quality deterioration downstream.

Evidence of temporal sequence-the cause must precede the ecological effect. Biological population density and ecological function are always stable. With urban sprawl, considerable habitats are converted into construction land, thereby resulting in the decline of biodiversity and the loss of ecological function.

Exposure-response relationships from the field-the intensity or frequency of hazardous effects at a site increases with increasing levels of exposure to the causal agent or decreases with decreasing levels. For example, $\mathrm{Pb}$ concentration decreases with distance from the expressway.

Causal pathway - the data of the causes are limited, and the causal pathway can provide supplementary or surrogate evidence. For example, high-intensity irrigation is one of the major causes of soil salinization, and the application of pesticides poses high risks to human health through the food chain.

Evidence of exposure mechanism - relevant exposure of candidate cause is founded, such as a large number of industrial exhaust emissions triggering fog and haze weather through atmospheric deposition, while causing respiratory illness of local residents.

Manipulation of exposure-a cause is manipulated to determine whether it can decrease or increase its ecological effect by eliminating or altering exposure. The limited discharge of industrial sewage has improved water quality in polluted water.

Symptoms-a set of symptoms may be used to diagnose a particular cause if they are unique to that cause. For example, mineralized water and large-scale sulfur precipitation are common around mining areas.

Types of evidence that use data from elsewhere:

Exposure-response relationships from other filed studies-at the diagnosed area, the cause must be at levels sufficient to cause similar hazards effects in other filed studies. For example, a huge amount of plastic mulch was abandoned in the damage sites with the widespread use of farm greenhouses. This scale of agricultural plastic waste per hectare has led to a serious "white pollution" in other similar areas, which causes long-term potential hazards due to the inability of soil to transform plastics.

Exposure-response relationships from laboratory studies-the candidate cause must be at levels associated with related hazardous effects in laboratory studies. For example, sewage irrigation brings great harm to agricultural production and is not easily detected. Through the toxicological analysis of the lab work, the concentration of the toxicants in the wasted water is much higher than the safety standard in the water, which causes a great risk to food safety.

Analogous causes-agents similar to the causal agent at the impaired site should lead to similar effects at other sites. For example, Almond eucalyptus was introduced to China from Australia in the early stage. It grows fast and has high economic value, especially for paper making or as raw materials for construction. It was once the preferred economic tree for farmers. Later, it was found that the root system developed to absorb a lot of nutrients and water in the land; the surrounding plants will not survive because of the lack of nutrients. Moreover, it will lead to the desertification of soil in planting areas, which will cause the deterioration of the forest environment.

These applications were similar to those in previous studies using WOE.

\subsubsection{Scoring System}

A scoring system was established to assign a candidate cause to a category for each of the criterion described earlier. Then, various pieces of evidence were assessed by 
ecological experts and land resource stakeholders. The seven possible scores range from +++ for "convincingly supports" to - - - for "convincingly weakens" and 0 for neutral evidence, as follows: "+++ convincingly supports," "++ strongly supports," "+ somewhat supports," "0 neither supports nor weakens," "- somewhat weakens," "- - strongly weakens," and "- - - convincingly weakens" [38,59]. Consider a candidate cause with two types of evidence, each with scores of + , thereby providing a sum of $++(1+1=2)$, and another candidate with three types of evidence with scores of,+++++ , and --$(3+2-3=2)$. Although sum 2 represents a possibility, the triple negative $(---)$ score may be sufficiently strong to refute the candidate cause $[54,60]$ These candidate causes present the following four categories: probable cause (with many "+++"), possible cause (with some "+" or " ++"), unlikely cause (with many " - - -"), and delayed cause (lack of evidence or available data) (Table 1).

\subsection{Analysis of Evidence}

We performed an analysis to evaluate data from the case and elsewhere. Then, such evidence was used to support or weaken the hypothesis that causes certain damages [38,42,54,59]. Our group presented no details of candidate causes due to constraints in time and working conditions. The research team will continue searching for evidence to test our causal hypothesis in the subsequent ecological restoration of land ecosystems. This approach was selected to obtain a relatively complete causal analysis of land degradation on the regional level.

\subsubsection{Probable Cause}

\section{- Habitat alteration}

The remote sensing data of Daye City from 1995 to 2015 indicate that the urban sprawl has been persistently popular, and large areas of water, forest, grassland, wetland, tidal flat, and paddy field are transformed into construction land [61-63]. The data of five-phase remote sensing interpretations from 1995 to 2013 indicated that the analysis of watershed conversion showed that the intensity of watershed to farmland was $3.85 \%$, and the number of lakes decreased from 309 in 1995 to 84 in 2013. For example, the areas of Bao'an and Daye Lakes decreased by $23.67 \%$ and $16.25 \%$, respectively, compared with their areas in 1995 .

- Heavy metal accumulation

Mining and processing industries, such as ore dressing and washing and metal smelting and forging, cause the discharge of a substantial amount of untreated industrial wastewater, thereby resulting in serious heavy metal pollution in the surrounding soil and water environments [64,65]. Based on the National Soil Environmental Quality Standard (GB15618-1995) and the background value of soil heavy metals (the values of $\mathrm{Cu}, \mathrm{As}, \mathrm{Cd}$, and $\mathrm{Pb}$ were adopted as $30.7,12.3,0.17,26.7)$, the content of heavy metals in regional soil was evaluated using Nemerow index [66,67]. Interestingly, no metal deposit was found in Chengui Town. However, this town is highly contaminated with $\mathrm{Cu}, \mathrm{Pb}$, and As because it is the area of concentration of the rough ore processing industry given the convenient advantage of the main traffic road in Daye City. The heavy metal pollution phenomenon is complex.

The environmental protection department conducted sampling and testing of the water and sediment quality of Daye Lake due to the river pollution problem caused by local $\mathrm{Cu}$ mining. The water quality data show that $\mathrm{Cu}$ concentration ranges from $34 \mathrm{mg} / \mathrm{L}$ near the wastewater discharge of $\mathrm{Cu}$ mines to $18 \mathrm{mg} / \mathrm{L}$ in several downstream estuaries. That is more than 15,500 times the normal water area. Meanwhile, $\mathrm{Cu}$ pollutants present a significant gradient, and the polluted area exhibits an expanding trend [68,69]. In addition, the $\mathrm{pH}$ value of acidic $\mathrm{Cu}$ wastewater ranges from 1.8 to 2.2, which is a mixed solution that contains high concentrations of ferric sulfate, $\mathrm{Cu}$, and $\mathrm{Al}$. This solution enriches heavy metal ions in the river and seriously deteriorates water quality.

- Organic pollutants 
Soil sampling in agricultural areas shows high concentrations of polycyclic aromatic hydrocarbons (PAHs) and polychlorinated benzene residues, thereby indicating the widespread use of pesticides and herbicides [70,71]. In traditional forest areas, the concentration of arsenide, which is the main component of insecticides applied every quarter of the year, is high. The field sampling of chemical fertilizer compost indicates that soil is enriched with phosphorus and Cd. This area is neither a mining nor an industrial processing area, but it is speculated to be affected by the use of a toxic phosphate fertilizer that contains Cd [72]. Statistics on the composition of agricultural fertilizers in various towns for several years are as follows: $45 \%$ nitrogen, $64.5 \%$ organic phosphate, $55.5 \%$ potassium, and $12 \%$ compound fertilizer.

The deterioration of water bodies caused by the application of pesticides and fertilizers is primarily due to rain-wash and seepage. The group investigated many lakes and pits around the cultivated land to search for evidence of organic pollution because organic pollutants are difficult to dissolve in water. The subsequent experiments indicate the impairment of the water environment by organic toxicants, particularly the identified three types of organic poisons: PAHs, organic chlorobenzene, and dichlorodiphenyltrichloroethane. The group conducted several on-site comparisons of wastewater discharge from paper mills and ammonia plants by focusing on the hazards posed to aquatic organisms by organic poison emissions $[73,74]$. Nearly no aquatic plants were found in the sewage outlet waters, and no evident aquatic plant was visible until $1800 \mathrm{~m}$ away $[75,76]$.

- Water eutrophication

Daye City has extensive water areas. Thus, the large-scale development of traditional aquaculture has contributed to water quality deterioration. The application of a large amount of organic feeds and long-term high-phosphorus fertilizers caused the high phosphorus enrichment of the lakes $[77,78]$. This phenomenon is the major cause of the high eutrophication of a water body [79]. Statistics show that up to $70 \%$ of organic phosphate fertilizers are applied in towns, and the high phosphorus content exceeds standards. Moreover, the amount of excreta produced by livestock farming without strict environmental protection treatment is 318,600 tons/year. These waste materials enter water areas through artificial dumping and rainstorms.

\section{- Nutrient runoff}

A high-intensity farming model is supported by the government to ensure grain yield, which results in an ineffective supplementation of land fertility, and eventually leads to the barren condition of cultivated lands [80,81]. The four-phase strength indexes of reclamation in Daye City are 3.2, 3.0, 2.8, and 3.2, which are considerably higher than those in other counties and cities in the province. For soil samples in the study area, nitrogen, phosphorus, and potassium contents were substantially reduced, but $\mathrm{Cl}$ content was several times higher than those in other areas, thereby indicating the leaching effect.

\subsubsection{Possible Causes}

\section{- Noxious gas}

A substantial amount of harmful gas, such as $\mathrm{CO}, \mathrm{NO}, \mathrm{H} 2 \mathrm{~S}$, and $\mathrm{SO} 2$, is produced by the coal-burning process of the metallurgical industry. These gases disperse in the atmosphere around mining areas [82,83]. The spontaneous combustion of coal gangue piles is widespread, and 27 cases are confirmed [84]. We were eager to verify the harmful components of these irritating gases. However, verification was not performed due to the limited experimental conditions. Moreover, investigations on chronic disease and lung cancer cases were prohibited by the local health authorities. However, during the extensive visits made by our team, the residents around the mining areas generally claimed that air quality had deteriorated. Factory exhaust gases frequently irritated the nasal mucosa, and the frequency of acute respiratory diseases increased in winter.

- Toxicants 
Substantial amounts of mineral processing fluid and slag directly and indirectly flow into the surrounding soil and lakes through the illegal emissions of private metallurgy processing firms without qualified environmental equipment $[85,86]$. Such sewage and slag contain acute toxicants, mostly heavy metals and organic poisons [87]. In a spot test of several waste minerals in 2011-2015, the Environmental Protection Agency found that discharged wastewater contained highly toxic cyanide, up to $16.5 \mathrm{mg}$ per liter of water, which exceeded the national safety standard by over 33 times.

- Altered underground runoff

The high intensity pumping of groundwater can decrease regional groundwater level and underground runoff changes and cause large-scale ground subsidence, collapse, and cracking $[88,89]$. For example, the groundwater level of one banned coal mine dropped from $19 \mathrm{~m}$ to nearly $55 \mathrm{~m}$ (i.e., a decline of nearly $46 \mathrm{~m}$ ), and their water supply system was basically scrapped. At present, 136 irrigation wells and 25 pumping stations are available.

- Atmospheric deposition

Metal oxide dust emitted by the metallurgy industry enters the soil in the form of dust reduction through gravity, thereby forming a point-like pollution centered on the emitting plant with a radius of $2-4 \mathrm{~km}$. Soil sampling analysis performed around the metallurgy industry belt indicates that the $\mathrm{Pb}$ content of the soil surface ranges from 147.65 to $3490.40 \mathrm{mg} / \mathrm{kg}$. This finding shows a considerable decrease in gradient. During an investigation in an open mining area, a substantial amount of coal dust and other industrial dusts are produced through various processes, such as coal mining, blasting, crushing, loading, and transportation. Various cases of acute respiratory diseases and irritations are frequent among locals (whether toxic gas causes acute poisoning remains uncertain).

- Acid rain

Statistics show that the acid rain area is gradually expanding. The $\mathrm{pH}$ value of acid rain in Daye City is 2.1, which is under the severe category [90-92]. Metallurgy, petrification, thermal power, and mining are highly concentrated, and the sulfur dioxide emissions are 81,300 tons/yea. Thus, sulfur dioxide exceeds the national atmospheric standards and worsens acid rain pollution. The $\mathrm{pH}$ of soil samples is generally $2.7-3.2$, with a serious depletion trend [93]. Notably, acid rain contributes to heavy metals entering the human body through the food chain, thereby posing a considerable health risk [94]. In addition, sulfur deposition in the study area exceeds $11-24 \%$ of the critical load, which seriously pollutes the surrounding soil environment [95].

\subsubsection{Unlikely Causes}

- $\quad$ Altered hydrology

Large-scale engineering construction changes original habitats [96]. Meanwhile, water conservation and hydropower projects also exert various negative effects, such as hydrological changes, groundwater recession, and surface water shrinkage [97]. For the actual situation in Daye, some water conservation and hydropower projects selected for risk source investigation seem to be changing the hydrological environment.

- Altered earth surface runoff

The water supply of some important inland lakes is disturbed by several activities, such as the development of greenhouses, vegetable gardens, flowerbeds, and aquaculture. Over-retention may cause the shrinkage of rivers and lakes [98]. However, the 1995-2015 Water Resources Bureau yearbook survey indicates that the major rivers exhibit no cutoff period, and the lake water level presents no remarkable decrease during the period, except during extreme drought.

- Soil erosion

Soil erosion has resulted in a decrease in the area of cultivated land, soil fertility and crop yield, and a serious contradiction between man and land [99]. The degree of 
soil erosion was calculated by field soil samples include soil moisture and soil surface thickness. According to national industry standard sl190-96 soil erosion classification and classification standard, the majority of the study area was in mild soil erosion. Meanwhile, compared with other mining cities, there is also serious surface damage, but it is not soil erosion [100].

\subsubsection{Delayed Candidate Causes}

- Soil salinization

Soil salinization is a land quality degradation process that involves soil salinity and alkalinity caused by human-made improper water diversion irrigation [101]. The groundwater level rises above the critical depth due to high-intensity irrigation. During evaporation, salt enriches the surface layer of the soil, thereby forming saline soil [101,102]. In 2009-2018, irrigation measures, such as wells and pumping stations, increased annually and intensified groundwater extraction, which is one of the major soil salinization risks. Unreasonable irrigation had not alarmed local authorities until widespread degradation occurred in the study area.

- Soluble inorganic salts

The concentrations of Fe and sulfur in the soil test are considerably high and eventually exhibit enrichment. In the study area, the severe deposition and migration of sulfur led to the death of soil microbes, nutrient loss, and large-scale land impoverishment $[103,104]$. However, sulfur-containing pollutants remain unknown. Accumulation in several areas, such as open mines, concentrated plants, washing ponds, tailing ponds, and coal gangue piles, is common throughout the year. A large amount of soluble inorganic salts from waste ore slags flowing into the surrounding area are determined using long-term weathering and rainfall leaching approaches [105]. In this case, mineral salts infiltrate into the groundwater layer, thereby forming highly saline water, which poses a safety hazard to residents and their livestock [106]. During groundwater sampling, acid testing with high 2-methyl-4chloropropionate was not conducted due to constraints in the experiment schedule.

- Biological species invasion

The continuous development of the aquaculture industry, particularly the large-scale reproduction of freshwater products, such as scorpionfish, squid, and Mandarin fish, exerts a serious impact on native aquatic species [107]. Grass cultivation with a certain degree of sugar content for fish feeding is extensive, and the original vegetation along the riverside has already disappeared. These conditions are likely to change the food chain in the original aquatic habitat. Vegetation changes in the southern mountain forest area have also elicited attention. The large-scale planting of economic trees, such as camphor, bamboo and cypress trees, is implemented because the self-contracted business model has been promoted by the local government for many years.

- Pathogens

A large area of vegetation and crops has withered, and the yellow-leaf disease frequently occurs. This condition is attributed to water, soil, and crops, which are highly susceptible to pathogens [108]. Another factor is the huge amount of sulfur dioxide in exhaust gas from intensive smelting enterprises. The area also receives heavy acid rain. However, emission data, particularly those of $\mathrm{SO}_{2}$ and $\mathrm{H}_{2} \mathrm{~S}$, were unavailable from the Department of Environment. Hence, further work should be performed during the latter stage.

Subsequent evidence of candidate causes will be identified depending on future investigations and experimental analyses in our study region. 


\section{Results}

\subsection{Identification of the Candidate Causes}

A WOE table was constructed to interpret our evidence and the candidate causes were presented (Table 2).

The probable cause has convincing evidence to indicate the cause of obvious damages, such as habitat alteration, heavy metal accumulation, and water eutrophication. For example, the analysis of evidence of habitat alteration was presented. A large number of wetland habitats have been surrounded by lake reclamation under the continuous pressures of the agricultural economy. This is obviously key evidence of temporal sequence. Moreover, increased agricultural water withdrawals have led to long-term insufficient water supply, thereby resulting in a large shrinkage area of local lakes and wetlands. This is evidence of spatial/temporal co-occurrence of cause and effect. These pieces of evidence were convincing support for the cause of habitat alteration mostly destroying the ecological structure.

Next, let us analyze the cause of heavy metal accumulation. In a soil sampling test, the heavy metal elements $\mathrm{Cd}, \mathrm{Cu}, \mathrm{Pb}$, and As seriously exceeded the values of local soil background by $6.15,28.76,7.04$, and 9.53 times, respectively [13]. It is not only evidence of spatial/temporal co-occurrence, but also exposure-response relationships from the field. Additionally, our research team repeatedly sampled river bottom sludge at different locations. The result shows that $\mathrm{Cu}$ concentration in the river sediments gradually decreases from west to east, with evident accumulation in the river channel (related to the river flow direction). Obviously, this is a causal characteristic of the exposureresponse relationships from the field. This finding suggests a potential pollution hazard to downstream water quality.

Then, the evidence of spatial/temporal co-occurrence for water eutrophication was presented. Notably, algae outbreak frequently occurs in large areas and seriously affects the aquatic ecosystem of the study area. Similarly, the presence of a set of symptoms also increases confidence of the alternative cause. Therefore, this convincingly supports the cause-effect that water eutrophication causes serious water deterioration.

The possible cause has some convincing pieces of evidence that imply the possibility of damage, such as atmospheric deposition and altered underground runoff. For example, the different evidence for the cause of atmospheric deposition was described as follows. Soil sampling analysis along the polluted industrial and mining zones indicates that dust contains automobile exhaust emissions, industrial dust, petroleum hydrocarbon pollution, and pollutant leakage on both sides of the expressway. The test data of soil heavy metals are given in the previous section of analysis of evidence. It is obvious that the effect occurs at the same time and in the same place as the candidate causes. Moreover, a clear $\mathrm{Pb}$ pollution zone has formed on both sides of the expressway, and $\mathrm{Pb}$ concentration in the surrounding area decreases as distance from the road increases. Strong effect gradients of exposure for atmospheric deposition were observed at spatially correlated sites. We also actively use the types of evidence that use data from elsewhere. Just as observation data throughout the years show that the surfaces of surrounding large-scale plants and field crops are covered with dust, and the leaves of plants commonly turn yellow and fall to the ground. Simultaneous comparisons were made with similar biological effect studies related to other mining cities. 
Table 2. WOE for candidate causes and consistency of evidence.

\begin{tabular}{|c|c|c|c|c|c|c|c|c|c|c|c|}
\hline \multirow{2}{*}{ Candidate Cause } & \multirow{2}{*}{$\begin{array}{l}\text { Co-Occurrence } \\
\text { (Spatial and } \\
\text { Temporal) }\end{array}$} & \multirow{2}{*}{$\begin{array}{l}\text { Temporal } \\
\text { Sequence }\end{array}$} & \multicolumn{2}{|c|}{ Exposure-Response Relationship } & \multirow{2}{*}{$\begin{array}{l}\text { Causal } \\
\text { Pathway }\end{array}$} & \multirow{2}{*}{$\begin{array}{l}\text { Evidence of } \\
\text { Exposure } \\
\text { Mechanism }\end{array}$} & \multirow{2}{*}{$\begin{array}{l}\text { Manipulation } \\
\text { of Exposure }\end{array}$} & \multirow{2}{*}{$\begin{array}{c}\text { Set of } \\
\text { Symptoms }\end{array}$} & \multirow{2}{*}{$\begin{array}{c}\text { Expose-Response } \\
\text { Relationships from } \\
\text { Other Field Studies }\end{array}$} & \multirow{2}{*}{$\begin{array}{c}\text { Analogous } \\
\text { Causes }\end{array}$} & \multirow{2}{*}{$\begin{array}{c}\text { Conclusions of } \\
\text { Consistency of } \\
\text { Evidence }\end{array}$} \\
\hline & & & Field & Laboratory & & & & & & & \\
\hline Altered hydrology & -- & 0 & / & / & + & -- & I & 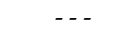 & 0 & / & Unlikely \\
\hline Destroyed earth surface & + & + & + & + & ++ & + & 0 & + & ++ & + & Probable \\
\hline Habitat remove & + & + & ++ & + & + & ++ & ++ & + & ++ & + & Probable \\
\hline Altered underground runoff & + & 0 & + & I & - & + & 0 & + & + & - & Possible \\
\hline Desertification & $\ldots$ & 0 & 0 & 1 & + & 0 & / & + & -- & + & Unlikely \\
\hline Soil erosion & 0 & 0 & - & -- & 0 & -. & / & + & -- & - & Unlikely \\
\hline Space occupation & 0 & $\cdots$ & + & 0 & + & + & -- & 0 & + & + & Unlikely \\
\hline Division of landscape & + & + & 0 & + & + & + & / & + & ++ & + & Probable \\
\hline Edge effect & + & 0 & ++ & + & 0 & + & / & - & 0 & - & Possible \\
\hline Soil salinization & + & 0 & / & / & + & 0 & / & 0 & 0 & + & Delayed \\
\hline Soil acidification & + & 0 & + & + & + & + & 1 & + & + & + & Probable \\
\hline Solubility inorganic salt & 0 & 0 & + & 0 & 0 & + & 0 & 0 & 0 & - & Delayed \\
\hline Nutrient runoff & + & + & ++ & + & + & + & / & + & + & + & Probable \\
\hline Organic pollutants & + & + & ++ & ++ & + & ++ & + & + & ++ & + & Probable \\
\hline Heavy metals accumulation & + & + & ++ & ++ & + & ++ & +++ & $\mathrm{D}$ & ++ & ++ & Probable \\
\hline Toxicants & 0 & 0 & + & + & - & + & 0 & 0 & + & + & Possible \\
\hline Leaching & 0 & 0 & ++ & 0 & 0 & + & +++ & $\mathrm{D}$ & + & + & Probable \\
\hline Water eutrophication & + & + & + & + & + & ++ & +++ & + & ++ & + & Probable \\
\hline Sulphur deposition & + & $\ldots$ & 0 & 0 & 0 & 0 & / & + & - & - & Delayed \\
\hline Noxious gas & 0 & + & + & / & - & + & / & + & 0 & - & Possible \\
\hline Acid rain & 0 & 0 & + & / & + & + & / & 0 & + & - & Possible \\
\hline Biological species invasion & 0 & 0 & + & / & 0 & + & / & 0 & 0 & + & Delayed \\
\hline Changes of the food chain & 0 & 0 & / & / & 0 & 0 & 0 & 0 & - & + & Delayed \\
\hline Geological disasters & + & + & + & + & + & ++ & / & + & + & + & Probable \\
\hline Population aggregation & $\ldots$ & 0 & / & / & + & + & / & 0 & - & - & Unlikely \\
\hline Farmland abandoned & + & $\mathrm{R}$ & + & / & + & + & -- & -- & - & + & Unlikely \\
\hline
\end{tabular}

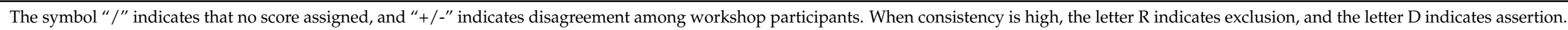


Then, we saw the candidate cause of altered underground runoff. We failed to obtain access to determine the specific engineering situation of mining companies. It certainly somewhat weakens the causality of the case. However, our team found pieces of evidence of abandoned mining. The groundwater level of one banned coal mine dropped. This is evidence of analogous causes that are similar to the causal agent in other sites/mines for a traditional mining city. Of course, we also have to use evidence from the types of evidence that use data from elsewhere, just like the following two pieces of evidence. One is in traditional Fe mining areas, where numerous mines pump out water all year round, thereby resulting in a decline in groundwater level. The other is irrigation, which is also one of the major factors that exert pressure on groundwater consumption learned, from the empirical literature [109].

The unlikely cause only has weak and non-persuasive evidence, such as altered hydrology and altered earth surface runoff. For example, consider the following two pieces of evidence spatial/temporal co-occurrence. No dry or broken flow in relevant rivers, significant change in water potential during rainstorm and flood seasons, and evidence of considerable changes in the hydrological pattern were not found. Ecological effects do not occur in the same place at the same time as candidate causes. Likewise, a substantial amount of water is consumed by numerous metallurgy industries because the water source is directly introduced from the Yangtze River, and no shortage of industrial water occurs. As mentioned earlier, Daye is along the Yangtze River system, which comprises vertical and horizontal lakes and abundant water resources. Such evidence indisputably suggested that there is no causal relationship.

The delayed cause lacks sufficient information/data to provide valid evidence at present, such as soil salinization and biological species invasion. The field survey did not diagnose soil salinization across the region. However, we calculated the irrigation intensity of each town on the basis of the statistics of the agricultural irrigation areas from 2001 to 2018. The results are higher than those of neighboring cities. This is explicitly an analogy using types of evidence that use data from elsewhere. It is generally recognized that a large amount of blind irrigation has caused serious soil salinization in many different countries. In subsequent experiments, soil salinity analysis should be continuously conducted in our sampling point.

Additionally, there is little experimental data to support a causal link for the cause of biological species invasion on the larger scale. However, we still cannot ignore the emergence of some symptoms evidence, as follows: statistics from the local agriculture bureau indicate a sharp decline in the population of original endemic fish species, such as pygmy icefish; the use of various fish feeds leads to changes in the water environment [110]; on the one hand, the large-scale planting of economic trees; on the other hand, the distribution of original plant species sharply decreases, thereby resulting in the loss of forest diversity and even the lack of food for animals [111,112]. Therefore, we still could not conclude that the phenomenon of biological species invasions did not occur in the Daye area. At a later stage, these possibilities of causal effects must be studied, and new causal analysis repeated where appropriate.

\subsection{Uncertainty Analysis}

Our group discussed the uncertainties of this causal analysis research in the following aspects. (1) In terms of time, data are not from one time dimension. Some survey data were obtained in summer, whereas others were collected during the rainy season, and thus, the influence of season is considerable. For example, the study area belongs to the drainage system of the Yangtze River, and the distance is only $39 \mathrm{~km}$. Therefore, runoff data change substantially with the flood season in the Yangtze River. (2) Data collection was limited. For example, water quality in 37 sampling sites does not cover all the water in Daye City. (3) Moreover, sensitive data, such as epidemic data on local health, leakage accidents, serious poisoning events, and food safety checks, were not obtained because permission from relevant departments was denied. (4) Although we were strict with regard 
to standards, three universities collaborated to perform our experiments, which may lead to errors in the experimental analysis. In particular, the level of ecological knowledge among different research teams varies. These reasons lead to uncertainties in our causal analysis research, and many hypotheses have not been proven by strong evidence. In summary, the application of the WOE method to causal analysis may be as quantitative as possible, logical, fair, convenient, and transparent. This method can draw on a wide range of interdisciplinary expertise to overcome the characterization of complicated ecological mechanisms on a broad scale.

\section{Discussion}

With the emergent contradiction between the tight supply of living resources and rapid population growth, the exploitation of wetland resources has long been an indisputable fact. Over the years, the farming model of lake area reclamation has caused the water area to shrink sharply [113].

Mining, as an inherent model of regional economic development, has intensified long-term heavy metal accumulation in soil in terms of degree and scope in the study area. In the traditional $\mathrm{Cu}$ mining areas, the concentration of $\mathrm{Cu}$ in soil is highly cumulative, thereby causing serious threats to river ecology, residential areas, cultivated land, and orchards along riverbanks. This condition will cause growth inhibition and toxicity, which will result in land productivity decline. Heavy metals pose harm to human health through the food chain. Therefore, government officials should be highly vigilant about food safety in this region. In particular, the accumulation of heavy metals in surrounding areas, such as ore piles, tailings ponds, and coal gangue piles, was serious and exhibited an evident decreasing trend. This phenomenon is attributed to long-term rainwater leaching, which causes the accumulation of heavy metals in large areas of soil surrounding a solid waste pile.

Estuary water quality exceeded the standard of heavy metal pollution, and the sediment analysis showed that $\mathrm{Cu}$ exhibited serious accumulation [114,115]. River pollution caused by $\mathrm{Cu}$ mining should be mitigated because it poses serious risks to downstream drinking water and breeding. Environment departments should set up additional monitoring points for water pollution and constantly monitor $\mathrm{Cu}$ concentration.

Fertilizer, pesticide, and film applications are the major sources of nonpoint source pollution. Statistics on the amount of agricultural fertilizer, pesticide, and film applied in Daye in 2012-2018 indicate that application strength was considerably higher than those in surrounding towns. In recent years, the cultivation technology of plastic mulch ground covering has developed rapidly. Hence, a substantial number of films have been abandoned in the field due to poor management. Solving this problem within a short period is difficult, thereby resulting in "white pollution" of the soil [116,117]. Pesticide residues are not allowed in the spot check of agricultural products due to the limitation of the local administration. Similarly, other categories of data on human health hazards from pesticides or other toxicants, such as acute or chronic poisoning incidents in the study area, are unavailable. However, we still speculate that huge amounts of pesticide residues have entered crops, thereby causing considerable harm to human health through the food chain [118-120].

The change in phosphorus content results from the alteration of land use patterns. The serious deterioration of water quality in many lakes is closely related to the development of the aquaculture industry in Daye area. Large-scale aquaculture has resulted in the eutrophication of water quality, which affects its self-purification capacity. Low phosphorus content inhibits the growth of aquatic plants. Therefore, local regulators should strengthen the supervision of feed application and consider the use of biological fertilizers.

Daye is located along the Yangtze River system, which includes lakes and rivers, and is rich in water resources. However, extensive irrigation systems have led to an annual dramatic increase in water use for agriculture due to the continuous drainage of groundwater by the mining industry [121]. Although direct underground runoff data are 
difficult to obtain, our group still infers that a significant change is highly probable in underground runoff. Irrigation intensity is considerably higher than those of surrounding cities. Many wells have dried up due to the declining groundwater level, and irrigation systems have become useless.

Dust storms occur in different seasons and are difficult to prevent. The topsoil in the surrounding area exhibits high $\mathrm{Pb}$ concentration, which easily forms dust and causes air pollution under the action of wind [122,123]. Although the expressway provides convenience for the production, processing, and transportation of the mining industry, which promotes the development of the local industrial economy, it is also an important potential risk source. Therefore, local environmental protection departments should pay attention to the usual dust reduction process, particularly in areas polluted by heavy metals. Severe acid deposition is primarily caused by urban industrial and mining agglomerations, with high concentrations of sulfur dioxide and nitrogen oxides in the air [91,93]. Acid rain accelerates soil acidification and the loss of mineral nutrients, thereby ultimately rendering the soil barren and uncultivable. Moreover, water acidification exerts a cumulative effect, which dissolves toxic substances into water and causes the death of aquatic organisms [94].

In summary, the aggregation of the mining and metallurgical processes results in the long-term deterioration of water, soil, and atmospheric environments in the study area, thereby forming extensive land degradation zones with complex mechanisms. This phenomenon not only affects the growth of plants and animals and poses considerable threat to human health, but also causes irreparable losses to the ecosystem.

\section{Conclusions}

Our study provides a suggested guideline for investigating possible causal relationships between ecological stressors and their effects on land ecosystems. Multiple lines of evidence based on the application of the WOE approach are applied to the causal analysis to determine land degradation on a regional scale. Although not all environmental causes can be identified, and many assumptions still need to be tested further, this research is sufficiently useful in acquiring a considerable amount of information, understanding mechanistic processes, and forming various ecological hypotheses.

Simultaneously, this work provides an effective decision-making basis for the management and restoration of damaged land ecosystems. First, the causal analysis of land ecosystems has expanded the methods for regional land ecological investigation, which exhibit practical operational significance. Second, hypothesis design for the complex mechanisms of land degradation has also enhanced the understanding of the ecological process on the regional scale. Third, the advantage of combining qualitative and quantitative methods/analyses is that they not only capture key issues but also ensure the accuracy of quantitative risk research, including exposure response, evaluation, prediction, decision making, and uncertainty analysis, in the latter stage. Lastly, the design of this causal analysis approach has been widely recognized by different stakeholders of land resources as the basis of decision-making tools. The causal analysis established for an impaired land ecosystem has effectively identified major hazard causes and their action mechanisms on a regional scale. This finding contributes to the formation of a stable and healthy land use relationship. It is also crucial for ecological protection and the sustainable utilization of resources.

In future research work, attention should be paid to other heavy metal elements involved in urban soil pollution, such as the investigation and analysis of heavy metal Cr. In addition, too high sulfur concentration in soil samples is also worthy of attention, although its migration is still uncertain. At present, most urban residents drink water from the Yangtze River, but most rural residents still drink groundwater. However, groundwater mineralization causes a huge health hazard, which has not been confirmed. Moreover, the attention to rural residential areas is not enough, especially ignoring the health hazard of humans and livestock during land degradation. In the following work, a health survey will be included in the survey on regional land resources and environment. Additionally, it 
is necessary to pay attention to providing a legal basis for ecological damage caused by specific harmful ways.

Exposure-response analysis in the risk research on regional land degradation is also a difficult link. In the following work, it is necessary to continue to improve the causal investigation to further reveal the complex degradation mechanisms (physics, chemistry, biology and humanity) at the regional level. On this basis, a complete exposure-response analysis can better display the process of large-scale land degradation.

Currently, the research on tracing the causes of large-scale land degradation, identifying the risk sources and revealing the ecological mechanisms are mostly based on qualitative approaches, which are highly subjective. This requires us to design excellent experiments for attribution analysis. However, experimental design is difficult for the complex land habitat system, and it is not clear how much confidence will be obtained from the poorly designed experiment. Therefore, the next experiments should rely on the causal probability of statistical correlation, and we should also pay attention to the development of quantitative causal evaluation tools.

Author Contributions: Conceptualization, K.G. and Y.C.; methodology, K.G. and Y.C.; formal analysis, K.G., Y.C., M.C., C.W.; investigation, K.G., Y.C., M.C., W.C., Z.C., R.L., W.F. and M.J.; resources, Y.C., C.W.; data curation, Z.C., W.C., R.L., W.F. and M.J.; writing—original draft preparation, K.G.; writing - review and editing, Y.C. and Z.C.; supervision, Y.C. and K.G.; project administration, Y.C. and C.W.; funding acquisition, K.G. and Y.C. All authors have read and agreed to the published version of the manuscript.

Funding: This research was funded by the National Natural Science Foundation of China (Grant No. 42071441), and the Risk Identification and Prevention Decision of Land Ecosystem at Regional Level (Grant No. 62003262), and the Fundamental Research Funds for the Central Universities (Grant No. 2042020kf0201).

Institutional Review Board Statement: Not applicable.

Informed Consent Statement: Not applicable.

Acknowledgments: The authors would like to thank Yanfang Liu (Wuhan University, China) for offering data related to the land resources of Daye City. We also thank the Land Resources Bureau of Daye City and Yuan Wan of Hubei Normal University for their kind help with the field investigation.

Conflicts of Interest: The authors declare no conflict of interest. The authors declare that they have no known competing financial interests or personal relationships that could have appeared to influence the work reported in this paper.

\section{References}

1. Turner, K.G.; Anderson, S.; Gonzales-Chang, M.; Costanza, R.; Courville, S.; Dalgaard, T.; Dominati, E.; Kubiszewski, I.; Ogilvy, S.; Porfirio, L.; et al. A review of methods, data, and models to assess changes in the value of ecosystem services from land degradation and restoration. Ecol. Model. 2016, 319, 190-207. [CrossRef]

2. Guo, K.; Zhang, X.; Liu, J.; Wu, Z.; Chen, M.; Zhang, K.; Chen, Y. Establishment of an integrated decision-making method for planning the ecological restoration of terrestrial ecosystems. Sci. Total Environ. 2020, 741, 139852. [CrossRef]

3. Liu, J.G.; Diamond, J. China's environment in a globalizing world. Nature 2005, 435, 1179-1186. [CrossRef]

4. Vesalon, L.; Cretan, R. Mono-industrialism and the struggle for alternative development: The case of the Rosia montana gold-ming project. Tijdschr. Econ. Soc. Geogr. 2013, 104, 539-555. [CrossRef]

5. Velicu, I. De-growing environmental justice: Reflections from anti-mining movements in Eastern Europe. Ecol. Econ. 2019, 159, 271-278. [CrossRef]

6. Liu, J.; Li, N.; Zhang, W.; Wei, X.; Tsang, D.C.; Sun, Y.; Luo, X.; Bao, Z.; Zheng, W.; Wang, J.; et al. Thallium contamination in farmlands and common vegetables in a pyrite mining city and potential health risks. Environ. Pollut. 2019, 248, 906-915. [CrossRef]

7. Bănăduc, D.; Curtean-Bănăduc, A.; Cianfaglione, K.; Akeroyd, J.; Cioca, L.-I. Proposed Environmental Risk Management Elements in a Carpathian Valley Basin, within the Roşia Montană European Historical Mining Area. Int. J. Environ. Res. Public Health 2021, 18, 4565. [CrossRef]

8. Vesalon, L.; Cretan, R. 'Cyanide kills!' Environmental movements and the construction of environmental risk at Rosia Montana, Romania. Area 2013, 45, 443-451. [CrossRef] 
9. Kaiser-Bunbury, C.N.; Mougal, J.; Whittington, A.E.; Valentin, T.; Gabriel, J.M.T.V.R.; Olesen, J.M.; Blüthgen, C.N.K.-B.N. Ecosystem restoration strengthens pollination network resilience and function. Nature 2017, 542, 223-227. [CrossRef]

10. Tang, Z.; Chai, M.; Cheng, J.; Jin, J.; Yang, Y.; Nie, Z.; Huang, Q.; Li, Y. Contamination and health risks of heavy metals in street dust from a coal-mining city in eastern China. Ecotoxicol. Environ. Saf. 2017, 138, 83-91. [CrossRef] [PubMed]

11. Tepanosyan, G.; Sahakyan, L.; Maghakyan, N.; Saghatelyan, A. Combination of compositional data analysis and machine learning approaches to identify sources and geochemical associations of potentially toxic elements in soil and assess the associated human health risk in a mining city. Environ. Pollut. 2020, 261, 114210. [CrossRef] [PubMed]

12. Pastorok, R.A.; Bartell, S.M.; Ferson, S.; Ginzburg, L.R. Ecological Modeling in Risk Assessment: Chemical Effects on Populations, Ecosystems, and Landscapes; CRC Press: Boca Raton, FL, USA, 2016.

13. Chen, R.; Ye, C. Resolving soil pollution in China. Nature 2014, 505, 483. [CrossRef] [PubMed]

14. Guo, K.; Liu, Y.; Zeng, C.; Chen, Y.; Wei, X. Global research on soil contamination from 1999 to 2012: A bibliometric analysis. Acta Agric. Scand. Sect. B Plant Soil Sci. 2014, 64, 377-391. [CrossRef]

15. Johnston, R.K.; Munns, W.R.; Tyler, P.L.; Marajh-Whittemore, P.R.; Finkelstein, K.; Munney, K.; Short, F.T.; Melville, A.; Hahn, S.P. Weighing the evidence of ecological risk from chemical contamination in the estuarine environment adjacent to the Portsmouth Naval Shipyard, Kittery, Maine, USA. Environ. Toxicol. Chem. Int. J. 2002, 21, 182-194. [CrossRef]

16. Wickwire, T.; Menzie, C.A. The Causal Analysis Framework: Refining Approaches and Expanding Multidisciplinary Applications. Hum. Ecol. Risk Assess. Int. J. 2010, 16, 10-18. [CrossRef]

17. Larsen, A.E.; Meng, K.; Kendall, B.E. Causal analysis in control-impact ecological studies with observational data. Methods Ecol. Evol. 2019, 10, 924-934. [CrossRef]

18. Vu, M.Q.; Le, Q.B.; Scholz, R.W.; Vlek, P.L. Detecting geographic hotspots of human-induced land degradation in Vietnam and characterization of their social-ecological types. In Proceedings of the 2012 IEEE International Geoscience and Remote Sensing Symposium, Munich, Germany, 22-27 July 2012; IEEE: Piscataway, NJ, USA, 2012; pp. 6220-6223. [CrossRef]

19. Wang, G.; Qian, J.; Cheng, G.; Lai, Y. Eco-environmental degradation and causal analysis in the source region of the Yellow River. Environ. Geol. 2021, 40, 884-890.

20. Zhang, L.; Zhang, L.; Xu, Y.; Zhou, P.; Yeh, C.-H. Evaluating urban land use efficiency with interacting criteria: An empirical study of cities in Jiangsu China. Land Use Policy 2020, 90, 104292. [CrossRef]

21. Feng, H.; Lim, C.W.; Chen, L.; Zhou, X.; Zhou, C.; Lin, Y. Sustainable Deforestation Evaluation Model and System Dynamics Analysis. Sci. World J. 2014, 2014, 1-14. [CrossRef]

22. Dale, V.H.; Kline, K.L. Issues in using landscape indicators to assess land changes. Ecol. Indic. 2013, 28, 91-99. [CrossRef]

23. Efroymson, R.A.; Kline, K.L.; Angelsen, A.; Verburg, P.H.; Dale, V.H.; Langeveld, J.W.; McBride, A. A causal analysis framework for land-use change and the potential role of bioenergy policy. Land Use Policy 2016, 59, 516-527. [CrossRef]

24. Vasconcelos, R.; Reis-Santos, P.; Fonseca, V.; Maia, A.; Ruano, M.; França, S.; Vinagre, C.; Costa, M.; Cabral, H. Assessing anthropogenic pressures on estuarine fish nurseries along the Portuguese coast: A multi-metric index and conceptual approach Sci. Total Environ. 2007, 374, 199-215. [CrossRef]

25. Giubilato, E.; Zabeo, A.; Critto, A.; Giove, S.; Bierkens, J.; Hond, E.D.; Marcomini, A. A risk-based methodology for ranking environmental chemical stressors at the regional scale. Environ. Int. 2014, 65, 41-53. [CrossRef] [PubMed]

26. Vu, Q.M.; Le, Q.B.; Frossard, E.; Vlek, P.L. Socio-economic and biophysical determinants of land degradation in Vietnam: An integrated causal analysis at the national level. Land Use Policy 2014, 36, 605-617. [CrossRef]

27. Riseng, C.M.; Wiley, M.J.; Black, R.W.; Munn, M.D. Impacts of agricultural land use on biological integrity: A causal analysis. Ecol. Appl. 2011, 21, 3128-3146. [CrossRef]

28. Meyfroidt, P. Approaches and terminology for causal analysis in land systems science. J. Land Use Sci. 2016, 11, 501-522 [CrossRef]

29. Serveiss, V.B.; Bowen, J.L.; Dow, D.; Valiela, I. Using Ecological Risk Assessment to Identify the Major Anthropogenic Stressor in the Waquoit Bay Watershed, Cape Cod, Massachusetts. Environ. Manag. 2004, 33, 730-740. [CrossRef]

30. Cheng, H.; Shen, R.; Chen, Y.; Wan, Q.; Shi, T.; Wang, J.; Wan, Y.; Hong, Y.; Li, X. Estimating heavy metal concentrations in suburban soils with reflectance spectroscopy. Geoderma 2019, 336, 59-67. [CrossRef]

31. Cormier, S.; Norton, S.; Suter, G.; Reed-Judkins, D. Stressor Identification Guidance Document; U.S. Environmental Protection Agency: Washington, DC, USA, 2000.

32. Linkov, I.; Loney, D.; Cormier, S.; Satterstrom, F.K.; Bridges, T. Weight-of-evidence evaluation in environmental assessment: Review of qualitative and quantitative approaches. Sci. Total Environ. 2009, 407, 5199-5205. [CrossRef]

33. Suter, G.W.; Cormier, S.M. Why and how to combine evidence in environmental assessments: Weighing evidence and building cases. Sci. Total Environ. 2011, 409, 1406-1417. [CrossRef]

34. Burton, G.A.; Chapman, P.M.; Smith, E.P. Weight-of-Evidence Approaches for Assessing Ecosystem Impairment. Hum. Ecol. Risk Assess. Int. J. 2002, 8, 1657-1673. [CrossRef]

35. Weed, D.L. Weight of Evidence: A Review of Concept and Methods. Risk Anal. 2005, 25, 1545-1557. [CrossRef] [PubMed]

36. Linder, S.H.; Delclos, G.; Sexton, K. Making Causal Claims about Environmentally Induced Adverse Effects. Hum. Ecol. Risk Assess. Int. J. 2010, 16, 35-52. [CrossRef]

37. Cormier, S.M.; Paul, J.F.; Spehar, R.L.; Shaw-Allen, P.; Berry, W.J.; Suter, G.W. Using Field Data and Weight of Evidence to Develop Water Quality Criteria. Integr. Environ. Assess. Manag. 2008, 4, 490-504. [CrossRef] [PubMed] 
38. Suter, G.W.; Norton, S.B.; Cormier, S.M. The Science and Philosophy of a Method for Assessing Environmental Causes. Hum. Ecol. Risk Assess. Int. J. 2010, 16, 19-34. [CrossRef]

39. Burton, G.A.; Batley, G.E.; Chapman, P.M.; Forbes, V.E.; Smith, E.P.; Reynoldson, T.; Schlekat, C.E.; Besten, P.J.D.; Bailer, A.J.; Green, A.S.; et al. A Weight-of-Evidence Framework for Assessing Sediment (Or Other) Contamination: Improving Certainty in the Decision-Making Process. Hum. Ecol. Risk Assess. Int. J. 2002, 8, 1675-1696. [CrossRef]

40. Smith, E.P.; Lipkovich, I.; Ye, K. Weight-of-Evidence (WOE): Quantitative Estimation of Probability of Impairment for Individual and Multiple Lines of Evidence. Hum. Ecol. Risk Assess. Int. J. 2002, 8, 1585-1596. [CrossRef]

41. Collier, T.K.; Adams, S.M. Establishing Causal Relationships between Environmental Stressors and Biological Effects in Field Studies. Hum. Ecol. Risk Assess. Int. J. 2003, 9, 15. [CrossRef]

42. Haake, D.M.; Wilton, T.; Krier, K.; Stewart, A.J.; Cormier, S.M. Causal Assessment of Biological Impairment in the Little Floyd River, Iowa, USA. Hum. Ecol. Risk Assess Int. J. 2010, 16, 116-148. [CrossRef]

43. Shao, J.; Zhou, J.Q. Study on the influences of industry transformation on the sustainable development of resource-exhausted city space. Procedia Eng. 2011, 21, 421-427. [CrossRef]

44. Li, H.; Long, R.; Chen, H. Economic transition policies in Chinese resource-based cities: An overview of government efforts. Energy Policy 2013, 55, 251-260. [CrossRef]

45. Zhang, H.; Xiong, L.; Qiu, Y.; Zhou, D. How Have Political Incentives for Local Officials Reduced Environmental Pollution in Resource-Depleted Cities? Sustainability 2017, 9, 1941. [CrossRef]

46. Zhang, H.; Xiong, L.; Li, L.; Zhang, S. Political incentives, transformation efficiency and resource-exhausted cities. J. Clean. Prod. 2018, 196, 1418-1428. [CrossRef]

47. Cormier, S.M.; Norton, S.B.; Suter, G.W. The U.S. Environmental Protection Agency's Stressor Identification Guidance: A Process for Determining the Probable Causes of Biological Impairments. Hum. Ecol. Risk Assess. Int. J. 2003, 9, 1431-1443. [CrossRef]

48. Science Policy Council Handbook: Peer Review. Available online: https://www.epa.gov/iris/us-epa-2000-science-policycouncil-handbook-peer-review (accessed on 15 January 2019).

49. Ziegel, E.R.; Suter, G. Ecological Risk Assessment. Technometrics 1995, 37, 240. [CrossRef]

50. Guidelines for Ecological Risk Assessment. Available online: https:/ /www.epa.gov/risk/guidelines-ecological-risk-assessment (accessed on 3 December 2019).

51. Suter, G.; Efroymson, R.; Sample, B.; Jones, D. Ecological Risk Assessment for Contaminated Sites; Apple Academic Press: Boca Raton, FL, USA, 2000.

52. Platt, J.R. Strong Inference: Certain systematic methods of scientific thinking may produce much more rapid progress than others. Science 1964, 146, 347-353. [CrossRef]

53. Yu, G.; Feng, J.; Che, Y.; Lin, X.; Hu, L.; Yang, S. The identification and assessment of ecological risks for land consolidation based on the anticipation of ecosystem stabilization: A case study in Hubei Province, China. Land Use Policy 2010, 27, 293-303. [CrossRef]

54. Causal Analysis/Diagnosis Decision Information System (CADDIS). Available online: https://www.epa.gov/caddis (accessed on 16 February 2019).

55. Fox, G.A. Practical causal inference for ecoepidemiologists. J. Toxicol. Environ. Health Part A 1991, 33, 359-373. [CrossRef]

56. Hill, A.B. The Environment and Disease: Association or Causation? Proc. R. Soc. Med. 1965, 58, 295-300. [CrossRef]

57. Glass, R.I. New prospects for epidemiologic investigations. Science 1986, 234, 951-955. [CrossRef]

58. Gard, N.W.; Menzie, C.A. A Causal/Risk Analysis Framework for Informing Endangered Species Jeopardy Reviews for Pesticides. In Pesticide Regulation and the Endangered Species Act; American Chemical Society: Washington, DC, USA, 2012 ; pp. $243-257$.

59. Cormier, S.M.; Suter, G.W.; Norton, S.B. Causal Characteristics for Ecoepidemiology. Hum. Ecol. Risk Assess. Int. J. 2010, 16, 53-73. [CrossRef]

60. Application of Watershed Ecological Risk Assessment Methods to Watershed Management. Available online: https://cfpub.epa. gov/ncea/risk/era/recordisplay.cfm?deid=162845 (accessed on 19 March 2020).

61. Su, S.; Ma, X.; Xiao, R. Agricultural landscape pattern changes in response to urbanization at ecoregional scale. Ecol. Indic. 2014, 40, 10-18. [CrossRef]

62. Su, S.; Xiao, R.; Li, D.; Hu, Y. Impacts of Transportation Routes on Landscape Diversity: A Comparison of Different Route Types and Their Combined Effects. Environ. Manag. 2013, 53, 636-647. [CrossRef] [PubMed]

63. Weilenmann, B.; Seidl, I.; Schulz, T. The socio-economic determinants of urban sprawl between 1980 and 2010 in Switzerland. Landsc. Urban Plan. 2017, 157, 468-482. [CrossRef]

64. Wei, B.; Yang, L. A review of heavy metal contaminations in urban soils, urban road dusts and agricultural soils from China. Microchem. J. 2010, 94, 99-107. [CrossRef]

65. Cao, Y.; Bai, Z.; Zhou, W.; Zhang, X. Characteristic analysis and pattern evolution on landscape types in typical compound area of mine agriculture urban in Shanxi Province, China. Environ. Earth Sci. 2016, 75, 1-15. [CrossRef]

66. Zhang, J.T.; Sun, H. Differences of Nemerow Index Method and Fuzzy Comprehensive Evaluation Method in Evaluation Heavy Metal Pollution in Soil. Environ. Monit. Manag. Technol. 2016, 28, 27-31.

67. Fan, J.N.; Guo, L.; Zhang, M.J.; An, K.D.; Yang, X.; Shi, M.F.; He, X.M. Present Situation and Evaluation of Heavy Metals Pollution in Surface Soils of Key Areas and Surrounding Areas in Hubei. Environ. Monit. China 2020, 36, 96-104.

68. Purves, D. Contamination of Urban Garden Soils with Copper and Boron. Nature 1966, 210, 1077-1078. [CrossRef] 
69. Ren, H.-Y.; Zhuang, D.-F.; Singh, A.; Pan, J.-J.; Qiu, D.-S.; Shi, R.-H. Estimation of As and Cu Contamination in Agricultural Soils Around a Mining Area by Reflectance Spectroscopy: A Case Study. Pedosphere 2009, 19, 719-726. [CrossRef]

70. Rasheed, T.; Bilal, M.; Nabeel, F.; Adeel, M.; Iqbal, H.M. Environmentally-related contaminants of high concern: Potential sources and analytical modalities for detection, quantification, and treatment. Environ. Int. 2019, 122, 52-66. [CrossRef] [PubMed]

71. Taiwo, A.M. A review of environmental and health effects of organochlorine pesticide residues in Africa. Chemosphere 2019, 220, 1126-1140. [CrossRef] [PubMed]

72. Luo, L.; Ma, Y.; Zhang, S.; Wei, D.; Zhu, Y.-G. An inventory of trace element inputs to agricultural soils in China. J. Environ. Manag. 2009, 90, 2524-2530. [CrossRef] [PubMed]

73. Ahmed, F.; Rodrigues, D.F. Investigation of acute effects of graphene oxide on wastewater microbial community: A case study. J. Hazard. Mater. 2013, 256-257, 33-39. [CrossRef] [PubMed]

74. Ma, X.; Wang, X.; Liu, Y.; Gao, J.; Wang, Y. Variations in toxicity of semi-coking wastewater treatment processes and their toxicity prediction. Ecotoxicol. Environ. Saf. 2017, 138, 163-169. [CrossRef] [PubMed]

75. Gros, M.; Petrović, M.; Ginebreda, A.; Barceló, D. Removal of pharmaceuticals during wastewater treatment and environmental risk assessment using hazard indexes. Environ. Int. 2010, 36, 15-26. [CrossRef]

76. Zhang, D.; Gersberg, R.M.; Ng, W.J.; Tan, S.K. Removal of pharmaceuticals and personal care products in aquatic plant-based systems: A review. Environ. Pollut. 2014, 184, 620-639. [CrossRef]

77. Couture, R.-M.; Tominaga, K.; Starrfelt, J.; Moe, S.J.; Kaste, Ø.; Wright, R.F. Modelling phosphorus loading and algal blooms in a Nordic agricultural catchment-lake system under changing land-use and climate. Environ. Sci. Process. Impacts 2014, 16, 1588-1599. [CrossRef]

78. Bowes, M.; Jarvie, H.; Halliday, S.; Skeffington, R.; Wade, A.; Loewenthal, M.; Gozzard, E.; Newman, J.; Palmer-Felgate, E. Characterising phosphorus and nitrate inputs to a rural river using high-frequency concentration-flow relationships. Sci. Total Environ. 2015, 511, 608-620. [CrossRef]

79. Meier, M.S.; Stoessel, F.; Jungbluth, N.; Juraske, R.; Schader, C.; Stolze, M. Environmental impacts of organic and conventional agricultural products-Are the differences captured by life cycle assessment? J. Environ. Manag. 2015, 149, 193-208. [CrossRef]

80. Tilman, D.; Cassman, K.G.; Matson, P.A.; Naylor, R.; Polasky, S. Agricultural sustainability and intensive production practices. Nature 2002, 418, 671-677. [CrossRef]

81. Mao, D.; Wang, Z.; Wu, B.; Zeng, Y.; Luo, L.; Zhang, B. Land degradation and restoration in the arid and semiarid zones of China: Quantified evidence and implications from satellites. Land Degrad. Dev. 2018, 29, 3841-3851. [CrossRef]

82. Lagny, C. The emissions of gases from abandoned mines: Role of atmospheric pressure changes and air temperature on the surface. Environ. Earth Sci. 2014, 71, 923-929. [CrossRef]

83. Lagny, C. Noxious gas emissions above former coal and iron mines in Lorraine due to the presence of iron sulphides. Environ. Earth Sci. 2015, 74, 6303-6313. [CrossRef]

84. Tan, W.-F.; Wang, L.-A.; Huang, C. Environmental effects of coal gangue and its utilization. Energy Source Part A Recovery Util. Environ. Eff. 2016, 38, 3716-3721. [CrossRef]

85. Déportes, I.; Benoit-Guyod, J.-L.; Zmirou, D. Hazard to man and the environment posed by the use of urban waste compost: A review. Sci. Total Environ. 1995, 172, 197-222. [CrossRef]

86. Venkatesan, A.K.; Done, H.Y.; Halden, R.U. United States National Sewage Sludge Repository at Arizona State University-A new resource and research tool for environmental scientists, engineers, and epidemiologists. Environ. Sci. Pollut. Res. 2015, 22, 1577-1586. [CrossRef] [PubMed]

87. Chen, J.L.; Ortiz, R.; Steele, T.W.; Stuckey, D.C. Toxicants inhibiting anaerobic digestion: A review. Biotechnol. Adv. 2014, 32, 1523-1534. [CrossRef]

88. Dou, X.S. A critical review of groundwater utilization and management in China's inland water shortage areas. Water Policy 2016, 18, 1367-1383. [CrossRef]

89. Khorrami, M.; Alizadeh, B.; Tousi, E.G.; Shakerian, M.; Maghsoudi, Y.; Rahgozar, P. How Groundwater Level Fluctuations and Geotechnical Properties Lead to Asymmetric Subsidence: A PSInSAR Analysis of Land Deformation over a Transit Corridor in the Los Angeles Metropolitan Area. Remote Sens. 2019, 11, 377. [CrossRef]

90. Larssen, T.; Carmichael, G. Acid rain and acidification in China: The importance of base cation deposition. Environ. Pollut. 2000, 110, 89-102. [CrossRef]

91. Larssen, T.; Lydersen, E.; Tang, D.; He, Y.; Gao, J.; Liu, H.; Duan, L.; Seip, H.M.; Vogt, R.D.; Mulder, J.; et al. Acid Rain in China. Environ. Sci. Technol. 2006, 40, 418-425. [CrossRef] [PubMed]

92. Zhang, F.; Hu, H.; Wang, L.; Zhou, Q.; Huang, X. Effects of rare earth and acid rain pollution on plant chloroplast ATP synthase and element contents at different growth stages. Chemosphere 2018, 194, 441-449. [CrossRef] [PubMed]

93. Moharami, S.; Jalali, M. Effect of acid rain on the fractionation of heavy metals and major elements in contaminated soils. Chem. Ecol. 2014, 31, 160-172. [CrossRef]

94. Singh, S.; Tripathi, D.K.; Singh, S.; Sharma, S.; Dubey, N.K.; Chauhan, D.K.; Vaculík, M. Toxicity of aluminium on various levels of plant cells and organism: A review. Environ. Exp. Bot. 2017, 137, 177-193. [CrossRef]

95. Fan, J.; Xu, Y.; Chen, Z.; Xiao, J.; Liu, D.; Luo, J.; Bolan, N.; Ding, W. Sulfur deposition suppressed nitrogen-induced soil $\mathrm{N}_{2} \mathrm{O}$ emission from a subtropical forestland in southeastern China. Agric. For. Meteorol. 2017, 233, 163-170. [CrossRef] 
96. Townsend, P.A.; Helmers, D.P.; Kingdon, C.C.; McNeil, B.E.; de Beurs, K.M.; Eshleman, K.N. Changes in the extent of surface mining and reclamation in the Central Appalachians detected using a 1976-2006 Landsat time series. Remote Sens. Environ. 2009, 113, 62-72. [CrossRef]

97. Dynesius, M.; Nilsson, C. Fragmentation and Flow Regulation of River Systems in the Northern Third of the World. Science 1994, 266, 753-762. [CrossRef]

98. Wang, F.; Ge, Q.; Yu, Q.; Wang, H.; Xu, X. Impacts of land-use and land-cover changes on river runoff in Yellow River basin for period of 1956-2012. Chin. Geogr. Sci. 2017, 27, 13-24. [CrossRef]

99. Lal, R.; Ahmadi, M.; Bajracharya, R.M. Erosional impacts on soil properties and corn yield on Alfisols in central Ohio. Land Degrad. Dev. 2000, 11,575-585. [CrossRef]

100. Vaezi, A.R.; Ahmadi, M.; Cerdà, A. Contribution of raindrop impact to the change of soil physical properties and water erosion under semi-arid rainfalls. Sci. Total Environ. 2017, 583, 382-392. [CrossRef]

101. Singh, A. Alternative management options for irrigation-induced salinization and waterlogging under different climatic conditions. Ecol. Indic. 2018, 90, 184-192. [CrossRef]

102. Pulido-Bosch, A.; Rigol-Sanchez, J.P.; Vallejos, A.; Andreu, J.M.; Ceron, J.C.; Molina-Sanchez, L.; Sola, F. Impacts of agricultural irrigation on groundwater salinity. Environ. Earth Sci. 2018, 77, 197. [CrossRef]

103. Mitchell, M.J.; Lovett, G.; Bailey, S.; Beall, F.; Burns, D.; Buso, D.; Clair, T.A.; Courchesne, F.; Duchesne, L.; Eimers, C.; et al. Comparisons of watershed sulfur budgets in southeast Canada and northeast US: New approaches and implications. Biogeochem. 2010, 103, 181-207. [CrossRef]

104. Vet, R.; Artz, R.S.; Carou, S.; Shaw, M.; Ro, C.-U.; Aas, W.; Baker, A.; Bowersox, V.C.; Dentener, F.; Galy-Lacaux, C.; et al. A global assessment of precipitation chemistry and deposition of sulfur, nitrogen, sea salt, base cations, organic acids, acidity and $\mathrm{pH}$, and phosphorus. Atmos. Environ. 2014, 93, 3-100. [CrossRef]

105. Quina, M.J.; Bordado, J.C.; Quinta-Ferreira, R.M. The influence of $\mathrm{pH}$ on the leaching behaviour of inorganic components from municipal solid waste APC residues. Waste Manag. 2009, 29, 2483-2493. [CrossRef]

106. Wang, B.; Peng, Y. The effect of saline water on mineral flotation-A critical review. Miner. Eng. 2014, 66-68, 13-24. [CrossRef]

107. Aschonitis, V.; Gavioli, A.; Lanzoni, M.; Fano, E.; Feld, C.; Castaldelli, G. Proposing priorities of intervention for the recovery of native fish populations using hierarchical ranking of environmental and exotic species impact. J. Environ. Manag. 2018, 210, 36-50. [CrossRef]

108. Santini, A.; Ghelardini, L.; De Pace, C.; Desprez-Loustau, M.L.; Capretti, P.; Chandelier, A.; Cech, T.; Chira, D.; Diamandis, S.; Gaitniekis, T.; et al. Biogeographical patterns and determinants of invasion by forest pathogens in Europe. New Phytol. 2013, 197, 238-250. [CrossRef]

109. Rodell, M.; Velicogna, I.; Famiglietti, J.S. Satellite-based estimates of groundwater depletion in India. Nature 2009, 460, $999-1002$. [CrossRef]

110. Aiken, J.K.; Findlay, C.S.; Chapleau, F. Long-term assessment of the effect of introduced predatory fish on minnow diversity in a regional protected area. Can. J. Fish. Aquat. Sci. 2012, 69, 1798-1805. [CrossRef]

111. Fridley, J.D.; Sax, D.F. The imbalance of nature: Revisiting a Darwinian framework for invasion biology. Glob. Ecol. Biogeogr. 2014, 23, 1157-1166. [CrossRef]

112. Warren, R.J.; Candeias, M.; Labatore, A.; Olejniczak, M.; Yang, L. Multiple mechanisms in woodland plant species invasion. J. Plant Ecol. 2019, 12, 201-209. [CrossRef]

113. Aumen, N.G.; Keddy, P.A. Wetland ecology: Principles and conservation. J. N. Am. Benthol. Soc. 2001, 20, 683-685. [CrossRef]

114. Liu, Y.; Li, W.; Wu, G.; Xu, X. Feasibility of estimating heavy metal contaminations in floodplain soils using laboratory-based hyperspectral data-A case study along Le'an River, China. Geo-Spatial Inf. Sci. 2011, 14, 10-16. [CrossRef]

115. Liu, Y.; Chen, Y. Feasibility of Estimating Cu Contamination in Floodplain Soils using VNIR Spectroscopy-A Case Study in the Le'an River Floodplain, China. Soil Sediment Contam. Int. J. 2012, 21, 951-969. [CrossRef]

116. Zhang, F.; Chen, X.; Vitousek, P. Chinese agriculture: An experiment for the world. Nature 2013, 497, 33-35. [CrossRef]

117. Liu, E.K.; He, W.Q.; Yan, C.R. 'White revolution' to 'white pollution'-Agricultural plastic film mulch in China. Environ. Res. Lett. 2014, 9, 091001. [CrossRef]

118. Bi, X.; Pan, X.; Zhou, S. Soil Security Is Alarming in China's Main Grain Producing Areas. Environ. Sci. Technol. 2013, 47, 7593-7594. [CrossRef]

119. Liu, Y.L.; Wen, C.; Liu, X.J. China's Food Security Soiled by Contamination. Science 2013, 339, 1382-1383. [CrossRef]

120. Tang, W.; Wang, D.; Wang, J.; Wu, Z.; Li, L.; Huang, M.; Xu, S.; Yan, D. Pyrethroid pesticide residues in the global environment: An overview. Chemosphere 2018, 191, 990-1007. [CrossRef]

121. Siebert, S.; Burke, J.; Faures, J.M.; Frenken, K.; Hoogeveen, J.; Döll, P.; Portmann, F.T. Groundwater use for irrigation-A global inventory. Hydrol. Earth Syst. Sci. 2010, 14, 1863-1880. [CrossRef]

122. Kang, J.; Choi, M.-S.; Lee, C.-B. Atmospheric metal and phosphorus concentrations, inputs, and their biogeochemical significances in the Japan/East Sea. Sci. Total Environ. 2009, 407, 2270-2284. [CrossRef]

123. Urrutia-Goyes, R.; Hernandez, N.; Carrillo-Gamboa, O.; Nigam, K.; Ornelas-Soto, N. Street dust from a heavily-populated and industrialized city: Evaluation of spatial distribution, origins, pollution, ecological risks and human health repercussions. Ecotoxicol. Environ. Saf. 2018, 159, 198-204. [CrossRef] 